\title{
Gas6/Axl Inhibits Osteosarcoma Apoptosis through Regulation of Apoptosis-Related Protein Bcl-2
}

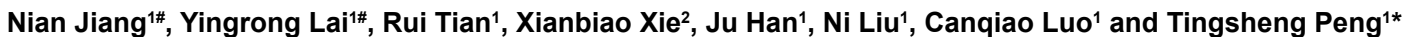

${ }^{1}$ Pathological Department, First Affiliated Hospital of Sun Yat-sen University, Guangzhou, P. R China

${ }^{2}$ Musculoskeletal Oncology Department, First Affiliated Hospital of Sun Yat-sen University, Guangzhou, P. R China

"Equally contributed

\begin{abstract}
Background: Dysregulation of the receptor tyrosine kinase Axl and its ligand Gas6 has been shown to promote the progression of osteosarcoma and correlates with poor prognosis. This study aimed to identify the role of Gas6/ Axl for anti-apoptosis as induced by cisplatin (DDP) and methotrexate (MTX) chemotherapy and to analyze the relationship between P-Axl and apoptosis-related proteins in osteosarcoma.
\end{abstract}

Method: Cultured osteosarcoma cell lines MG63, 143B and U2OS were used for apoptosis assays, AxI siRNA transfection, cytotoxicity assays, cell cycle analysis, and other assessment methods. A total of 41 cases of osteosarcoma patients were included for immunohistochemistry staining and clinicopathological relative analysis. TUNEL assay was performed in ten pair's cases for apoptosis detection and relative analysis of P-Axl.

Results: Among the osteosarcoma cell lines, Gas6 could obviously protect tumor cells from apoptosis induced by DDP and MTX by binding to $\mathrm{Axl}(\mathrm{P}<0.05)$. Axl siRNA transfection enhanced cell apoptosis, whereas Gas 6 was unable to function upon previous knockdown of Axl. Among the 41 osteosarcoma cases, the positive rate of Bcl-2, Bax, and P-AxI was $70.7 \%, 36.6 \%$, and $85.4 \%$, respectively. In osteofibrous dysplasia, the positive rate of them was $22.2 \%, 11.1 \%$, and $14.6 \%$, respectively. The expression levels of these apoptosis-related factors were significantly higher in osteosarcoma than in osteofibrous dysplasia $(P<0.05)$. Through clinico-pathological analysis, there were significant relationships between the survival status and $\mathrm{Bcl}-2$ or Bax expression $(\mathrm{P}<0.05)$. TUNEL assay also demonstrated that P-Axl high expression inhibited apoptosis in osteosarcoma tissues. By Cox univariate analysis, $\mathrm{Bcl}-2$ or Bax was correlated with the patients' prognosis. Importantly, Pearson correlation analysis demonstrated that $\mathrm{Bcl}-2$ was positively correlated to $\mathrm{P}-\mathrm{Axl}$ with statistical significance $(r=0.842, \mathrm{P}<0.0001)$.

Conclusion: Gas6/Axl protects osteosarcoma cells from the apoptosis induced by DDP and MTX chemotherapy and inhibits apoptosis in osteosarcoma tissue, possibly through the regulation of apoptosis-related protein Bcl-2.

Keywords: Osteosarcoma; Tyrosine kinase receptor Axl; Gas6; Apoptosis; Bcl-2; Prognosis

Abbreviations: RTKs: Receptor Tyrosine Kinases; Gas6: Growth Arrest-Specific 6; DDP: Cisplatin; MTX: Methotrexate

\section{Introduction}

Although the 5-year survival of osteosarcoma patients has been improved since the 1980s, further improvement in survival has not been achieved owing to a lack of well-validated prognostic markers and the problem of non-response to chemotherapy [1].

Axl was first isolated in chronic myelogenous leukemia, and then was characterized and given the name "Axl," derived from Greek term "anexelekto," or uncontrolled function [2,3]. Axl was cloned as the first TAM family tyrosine kinase receptor, and subsequent cloning of both Tyro3 and Mer in 1994 revealed the existence of similar domains in this family $[3,4]$. The TAM receptors are also grouped based on their common ligands, Gas6 and protein S. The Gas6 gene named from "growth arrest-specific" factors was cloned in 1988 [5]. Gas6/Axl binding complexes participate in the mediation of processes such as proliferation, apoptosis, migration and adhesion in both normal and disease settings [6].

Apoptosis, also known as programmed cell death, is triggered by many factors in the cell death program. Apoptosis is also related to the pathogenesis of many diseases and pathological cell death [7]. Some cancer treatments, such as chemotherapy, radiation and biological therapies are mostly used to induce apoptosis [8]. The Bcl-2 family is a class of apoptosis-related proteins, including the pro-apoptotic proteins (Bax, Bak, Bad, etc.) and anti-apoptotic proteins (Bcl-2, Bcl$\mathrm{xL}, \mathrm{Bcl}-\mathrm{w}$, etc.). The death signals act on the mitochondria, leading to mitochondrial outer membrane permeabilization and the release of cytochrome $\mathrm{C}$ through pro-apoptotic proteins [9]. The anti-apoptotic proteins can restrain the release of cytochrome $\mathrm{C}$ from the mitochondria to the cytoplasm. Bcl-2 and Bax are the most representative members of the Bcl-2 family, contributing greatly to the regulation of tumor cell apoptosis. There is increased Bcl-2 expression in most tumor tissues including breast cancer [10], prostate cancer [11]. On the other hand, in gastric cancer [12] and cutaneous Merkel cell carcinoma [13], Bax expression is obviously increased, while which decrease in colorectal cancer [14] and nasopharyngeal carcinoma [15]. As reported in nonsmall cell lung cancer [16], patients with Bcl-2 overexpression have poor clinical prognosis. In oral squamous cell carcinoma [17], patients with Bax-positive expression have a better prognosis. Thus, the expression of Bcl-2 and Bax is closely linked to the clinical prognosis.

*Corresponding author: Tingsheng Peng, 1st Affiliated Hospital of Sun Yat-sen University, Pathological Department, Guangzhou, PR China, Tel: 86-20-87331780; E-mail: pengtsh@mail.sysu.edu.cn

Received December 03, 2015; Accepted December 28, 2015; Published January 04, 2016

Citation: Jiang N, Lai Y, Tian R, Xie X, Han J, et al. (2016) Gas6/AxI Inhibits Osteosarcoma Apoptosis through Regulation of Apoptosis-Related Protein Bcl-2. J Bioanal Biomed 8: 001-008. doi:10.4172/1948-593X.1000145

Copyright: (C) 2016 Jiang N, et al. This is an open-access article distributed unde the terms of the Creative Commons Attribution License, which permits unrestricted use, distribution, and reproduction in any medium, provided the original author and source are credited. 
Bcl-2 was also been proved to be higly expressed in osteosarcoma, but the prognostic or predictive function of $\mathrm{Bcl}-2$ or Bax in osteosarcoma were still uncertain [18], a recent meta-analysis even suggested that the bcl-2 expression might be independent with the prognosis for patients with osteosarcoma [19].

As we have proven, osteosarcoma cells show increased levels of activated Axl which are correlated with clinical prognosis. In this setting, Axl protects tumor cells from apoptosis and promotes their invasion and migration, potentially contributing to lung metastasis. Phosphorylated Axl may mediate these effects through Akt signaling and the up regulation of matrix metalloproteinase 9 (MMP-9) [20]. However, studies on the exact inhibition of apoptosis by Axl and the anti-apoptotic mechanisms in osteosarcoma have been rarely reported [21]. ES Papadakis et al. have confirmed that Axl could negatively regulate pro-apoptotic Bcl-2 family members and promote cellular survival in cutaneous squamous cell carcinoma [22]. It is interesting to determine whether there is a similar mechanism for Axl to control apoptosis in osteosarcoma. In this study, we will focus on the role of Axl in inhibiting apoptosis in osteosarcoma and the relationship between activated Axl and the apoptosis-related proteins Bcl-2 and Bax.

\section{Method}

\section{Human osteosarcoma cell lines in culture}

The osteosarcoma cell lines MG63, 143B and U2OS were obtained from ATCC (American type culture collection). They were maintained in Dulbecco's modified Eagle's medium (DMEM) with $10 \%$ fetal bovine serum and $100 \mathrm{U} / \mathrm{ml}$ penicillin/streptomycin solution (Gibco, USA). All cell lines were incubated at $37^{\circ} \mathrm{C}$ in a humidified $5 \% \mathrm{CO}_{2}$ atmosphere.

\section{Patients and paraffin-embedded osteosarcoma tissues}

Paraffin-embedded biopsy samples were collected individually from 41 patients who presented to the First Affiliated Hospital of Sun Yat-sen University (Guangzhou, China) with primary non-metastatic osteosarcoma between 2010 and 2013. This population included 23 males and 18 females from 8 to 58 years old; the average patient age was 16.32 years. The patients were followed from 12 months to 124 months, with an average follow-up time of 75 months. Among them were 16 patients who died of the disease. Fresh samples were collected and immediately frozen at $-80^{\circ} \mathrm{C}$. Eighteen cases of osteofibrous dysplasia were used as a benign control lesion group.

\section{Antibodies and other reagents}

Antibodies against human phosphorylated Axl and recombinant human Gas6 were obtained from R\&D Systems (Minneapolis, MN, USA). Antibodies against human Bcl-2 and Bax and the HRPconjugated secondary antibodies (EnVision" FLEX Systems) were obtained from DAKO, Denmark. Cisplatin (DDP) and methotrexate (MTX) were obtained from Melonepharma, Dalian, China.

\section{Apoptosis detection with Hoechst 33258 staining}

MG63 and U2OS cells were pretreated with Gas6 at 0 or $400 \mathrm{ng} / \mathrm{ml}$ for 24 hours and then treated with $20 \mu \mathrm{g} / \mathrm{ml}$ DDP or $600 \mu \mathrm{g} / \mathrm{ml}$ MTX for 24 hours, respectively. Cells were subsequently stained with $1 \mu \mathrm{g} /$ $\mathrm{ml}$ Hoechst 33258 for 10 mins at room temperature in the dark, and photos were taken using a fluorescence microscope (Leica, Germany). The experiments were repeated three times. The inhibitory rates were calculated by the formula of 1-OD (treated) /OD (control), indicating the percentage of the apoptotic cells among the whole cells group.

\section{Transfection of Axl siRNA}

MG63 and 143B cells were harvested at $\log$ phase; $3 \times 10^{3}$ or $2 \times$ $10^{5}$ cells were seeded into 96 -well plates or 6 -well plates respectively in each experiment. After incubation in medium without serum for 4 hours, cells were transfected with small interference RNA targeting Axl (siRNA-Axl) at a final concentration of $50 \mathrm{nM}$ using the X-treme reagent (Roche, Indianapolis, IN, USA) according to the manufacturer's instructions. The negative control (RIBIO, Guangzhou, China) reactions were done simultaneously. Six hours later, the cells were transitioned back to full medium. The transfection efficiency was evaluated by qRT-PCR, and each experiment was repeated three times.

\section{Cellular cytotoxicity assay (MTT assay)}

MG63 and 143B cells were harvested at log phase, with $3 \times 10^{3}$ cells being seeded into 96-well plate. The negative control, Gas6 stimulation, Axl-siRNA transfection and Axl-siRNA plus Gas6 groups were set up separately in proliferation assays. The same groups were set up with DDP or MTX treatment in apoptosis assays. The cells were incubated overnight after seeding. After 4 hours of incubation in medium without serum, the Axl-siRNAs were transfected into the Axl-siRNA group and Axl-siRNA plus Gas6 group separately. After 6 hours of transfection, all groups were changed to medium without serum. Subsequently, 200 $\mathrm{ng} / \mathrm{ml}$ Gas6 was added into the medium of the Gas 6 group and the Axl-siRNA plus Gas6 group separately and kept for 24 hours. In the chemotherapy groups, the final concentration of DDP was $20 \mu \mathrm{g} / \mathrm{ml}$, and MTX was $300 \mu \mathrm{g} / \mathrm{ml}$. All the treatment groups were incubated with chemotherapy drugs for 24 hours. Finally, an MTT detection kit (Kaiji, China) was used to detect the proliferative rates and apoptotic rates of the cells with different treatments.

\section{Cellular apoptotic assay with annexin v-fitc staining}

MG63 cells were harvested at log phase and seeded into 6-well plates at $2 \times 10^{5}$ cells per well. Treatment groups were set up as with the MTT assay. After treating the cells with Axl-siRNA, Gas6, or the chemotherapy drugs DDP or MTX, an Annexin-V-FITC staining kit (Roche, Germany) was used on differentially treated groups according to the manufacturer's instructions. With Annexin-V-FITC staining, the cells were analyzed by flow cytometry at an excitation wavelength of $488 \mathrm{~nm}$ (Beckman Coulter, Fullerton, CA, USA). All the experiments were carried out independently at least three times.

\section{Cell cycle analysis}

A DNA content detecting kit (KeyGen, China) was utilized on MG63 and U2-OS cells. Gas6 was added to MG63 and U2OS cells at $\log$ phase at concentrations of $0,100,200$ or $400 \mathrm{ng} / \mathrm{ml}$ for 48 hours separately. After staining with PI, the cell cycle of each treatment sample was analyzed by flow cytometry at $488 \mathrm{~nm}$ (Beckman Coulter, USA). All the experiments were carried out independently at least three times.

\section{Immunohistochemical analysis}

An Envision two-step assay was used for immunohistochemical staining of P-Axl, Bcl-2 and Bax. Staining results were scored semiquantitatively based on the combined percentage [five-tiered algorithm for positive cells $(0: 0 \% ; 1:<25 \% ; 2: 25 \%-50 \% ; 3: 51 \%-75 \% ; 4:>75 \%)]$ and the intensity of cytoplasmic and nuclear staining [four-tiered system (0: negative; 1 : weak; 2 : moderate; 3 : strong)], and scores tabulated as the expression index [(percentage positive) $\times$ (intensity)]. The index scores of three pathologists were averaged to obtain the final expression index. For P-Axl grading, high expression was defined as a score of 2 or 
Citation: Jiang N, Lai Y, Tian R, Xie X, Han J, et al. (2016) Gas6/Axl Inhibits Osteosarcoma Apoptosis through Regulation of Apoptosis-Related Protein Bcl-2. J Bioanal Biomed 8: 001-008. doi:10.4172/1948-593X.1000145

more, and scores less than 2 were defined as low expression. For Bcl-2 and Bax, positive expression was defined as a score of 2 or greater and negative expression was defined as a score of 1 or lower.

\section{TUNEL assay in osteosarcoma tissue}

TUNEL assay was performed on paraffin-embedded tissue slides using the In situ Cell Death Detection Kit (Roche, Germany). Ten pairs of specimens with Axl high expression were compared to specimens with Axl low expression. All the slides were first deparaffinized; they were then rehydrated, put into $10 \mathrm{mM}$ citrate $\mathrm{pH} 6$ in a $95^{\circ}$ water bath for 30 minutes for permeabilization and further digested with $1 \mu \mathrm{g} / \mathrm{ml}$ proteinase $\mathrm{K}$ for 10 minutes at $37^{\circ}$. TUNEL reagents were then applied to the slides according to the manufacturers' instructions. Apoptotic cell counting was performed with fluorescence microscopy (Leica, Germany). After calculating the average positive numbers on every slide, the correlation between P-Axl expression and apoptotic rate in the same tissue was analyzed.

\section{Statistical analysis}

T-test analysis of two independent variables was used to test the differences between Bcl-2 and Bax expression in osteosarcoma and osteofibrous dysplasia tissues. Correlations between P-Axl, Bcl-2, Bax and the clinicopathological features were evaluated by chi-square or ANOVA testing. COX univariate regression analysis was performed to test the association of the osteosarcoma patients' prognosis and Bcl-2 and Bax expression. Spearman rank correlation and Pearson analysis were used to test the correlation between P-Axl, Bcl-2 and Bax expression in osteosarcoma tissues. Statistical analysis was conducted using SPSS 16.0 (SPSS, Inc., Chicago, IL, USA) with a 2-sided significance level of $\mathrm{P}<0.05$.

\section{Results}

\section{Gas6 promoted osteosarcoma resistance to DDP or MTX chemotherapy}

As indicated in Figure 1, in MG63 cells, the chemotherapy inhibitory rates were $42.6 \%$ and $21.9 \%$ with $20 \mu \mathrm{g} / \mathrm{ml} \mathrm{DDP} \mathrm{or} 600 \mu \mathrm{g} /$ $\mathrm{ml}$ MTX treatments respectively. With pretreatment of $400 \mathrm{ng} / \mathrm{ml}$ Gas6, the chemotherapy inhibitory rates of DDP or MTX at the same concentration were reduced to $29.8 \%$ and $6.4 \%$, respectively $(\mathrm{P}<0.05)$. The same experiment was repeated in U2OS cells pretreated with 400 $\mathrm{ng} / \mathrm{ml} \mathrm{rhGas6}$, and the inhibitory rate of chemotherapy decreased from $40.0 \%$ to $22.8 \%$ for DDP treatment and from $28.6 \%$ to $16.4 \%$ for MTX respectively $(\mathrm{P}<0.05)$ (Figures $1 \mathrm{~A}$ and $1 \mathrm{~B})$. Those results indicated that
A

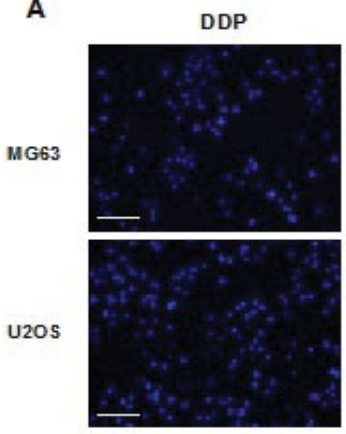

C
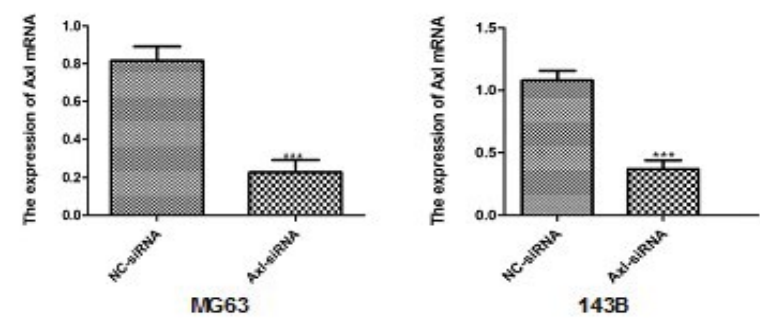

$\mathrm{DDP}+\mathrm{Gas} 6$

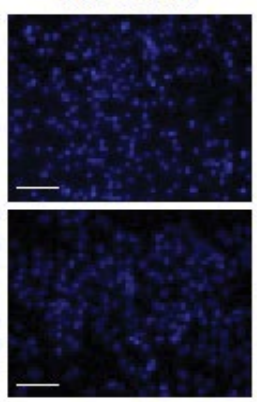

MTX

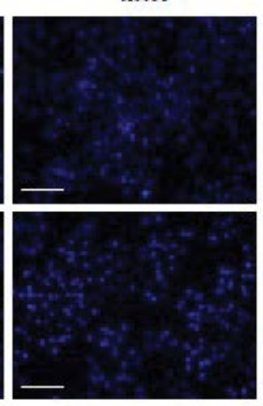

MTX + Gas6
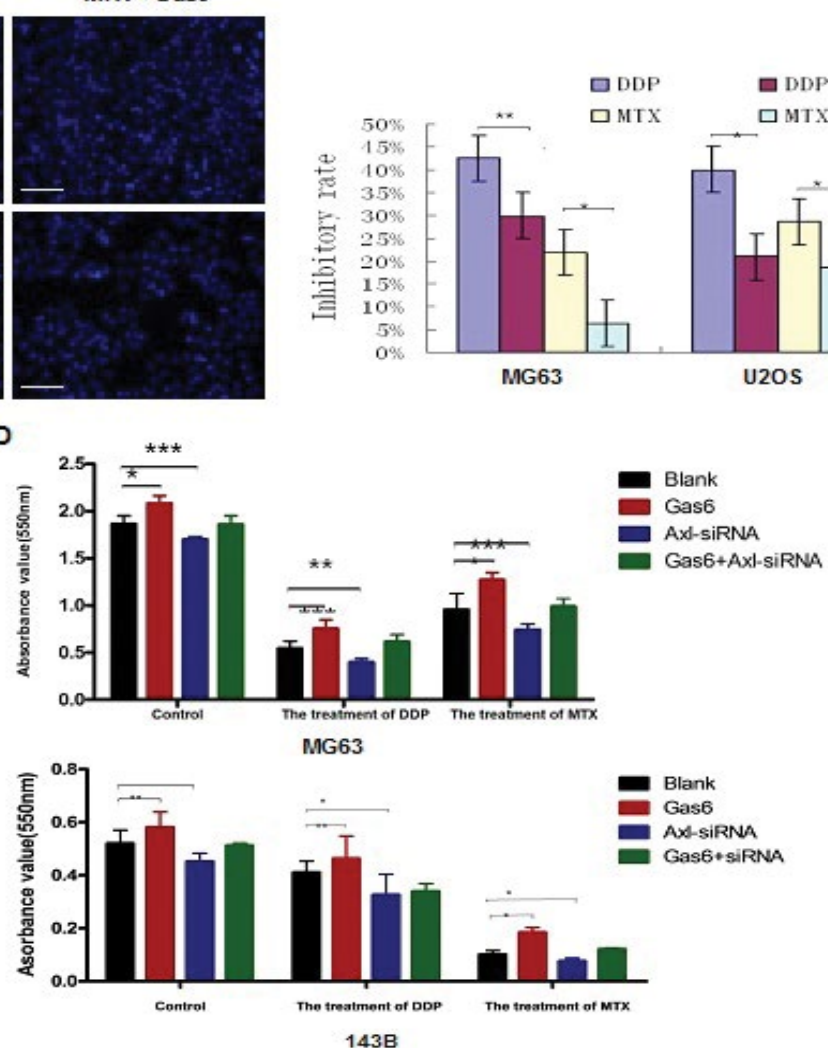

Figure 1: Gas6 promoted osteosarcoma resistance to DDP or MTX and protected osteosarcoma cells from cell death through binding to AxI. (A) MG63 or U2OS were treated with $20 \mu \mathrm{g} / \mathrm{ml}$ DDP or $600 \mu \mathrm{g} / \mathrm{ml}$ MTX and detected by fluorescent staining of nuclei with Hoechst 33258 . Parts of the cells were pre-treated with 400 $\mathrm{ng} / \mathrm{ml}$ extraneous recombined human Gas6 for 24 hours (The size bar represent $500 \mu \mathrm{m}$ ). (B) The inhibitory rates were calculated by the formula as $1-\mathrm{OD}$ (treated) IOD (control). The inhibitory rates decreased obviously with pre-treatment of $400 \mathrm{ng} / \mathrm{ml} \mathrm{Gas} 6(\mathrm{P}<0.05)$. (C) The content of Axl mRNA decreased obviously when MG63 or 143B were transfected with AxI siRNA (P<0.05). (D) MG63 or 143B were treated in three groups. In the control group the cells were cultured in medium without serum, treated with Gas6, Axl-siRNA transfection, or Axl-siRNA with Gas6 pre-treation. The second and third groups were set up as the same as the control group, with $20 \mu \mathrm{g} / \mathrm{ml} \mathrm{DDP}$ or $300 \mu \mathrm{g} / \mathrm{ml}$ MTX treatment separately. With the treatment of DDP or MTX, the OD value, which presented opposite to the apoptotic rate, decreased obviously compared to that of the control group $(\mathrm{P}<0.05)$. Among all the experimental groups, the cell proliferative rates increased with $\mathrm{Gas} 6$ pretreatment and decreased with Axl knockdown, and prior siRNA-mediated inhibition of Axl blocked Gas6 function. 
Citation: Jiang N, Lai Y, Tian R, Xie X, Han J, et al. (2016) Gas6/Axl Inhibits Osteosarcoma Apoptosis through Regulation of Apoptosis-Related Protein Bcl-2. J Bioanal Biomed 8: 001-008. doi:10.4172/1948-593X.1000145

Gas6 might promote osteosarcoma cell resistance to DDP or MTX chemotherapy.

\section{Gas6 protected osteosarcoma cells from cell death through ligand binding to its target receptor Axl}

After transfecting with Axl siRNA, the mRNA of Axl in MG63 and 143B cells were decreased obviously (Figure 1C). MG63 and $143 \mathrm{~B}$ cells were treated in different conditions (Figure 1D). With the treatment of $200 \mathrm{ng} / \mathrm{ml}$ Gas6, both of the OD values increased, which indicated that the role of Gas6 was to increase cell proliferation. On the contrary, the OD values decreased after Axl-siRNA transfection in both cell lines $(\mathrm{P}<0.05)$. Although the inhibitory effect of Axl-siRNA was counteracted with the re-stimulation of Gas6 later, there was no significant increase in OD value compared to that of the cells pretreated with Gas6 singly. Altogether, these results indicated that Gas6 may improve the proliferation of osteosarcoma cells through ligand binding to its target receptor Axl, and prior siRNA-mediated inhibition of Axl blocked Gas6 function. When cells were treated with the DDP or MTX, the OD value decreased relative to the control group $(\mathrm{P}<0.05)$. Consistent with the proliferative trend with no chemotherapy, Gas6 could support cell survival, and Axl-siRNA treatment enhanced cell death caused by chemotherapy.

\section{Gas6/Axl inhibited apoptosis of osteosarcoma cells caused by DDP or MTX}

Apoptosis was quantified by Annexin V-FITC staining to prove that Gas6/Axl protected osteosarcoma cells from apoptosis in the model cell MG63 (Figure 2A). The percent of apoptotic cells was $11.16 \%$ with no chemotherapy and increased to $16.9 \%$ or $17.67 \%$ with DDP or MTX treatment. In the control group, Gas6 stimulation decreased the apoptosis rate from $11.16 \%$ to $3.46 \%$; these results support an anti-apoptotic function of Gas6. On the contrary, the apoptosis rate of the cells with Axl-siRNA transfection increased dramatically to $30.09 \%$. After Axl-siRNA transfection, Gas6 could merely decrease the apoptotic rate to $27.79 \%$, which indicated that Gas6 almost could not change the apoptotic rate of cells with blocked Axl (Figure 2B). The apoptotic rates changed in the DDP or MTX treatment groups with a similar trend. Although DDP or MTX increased the apoptosis rates, Gas6 could still partially protect the cells from apoptosis, whereas Axl siRNA transfection enhanced cells apoptosis with chemotherapy drug treatment.

\section{Gas6/Axl inhibited the apoptosis with no effect on cell cycle}

To detect whether there was a relationship between the Gas6/Axl anti-apoptotic function and the cell cycle, a cell cycle detection assay was also performed. As shown in Figure 2C, the G1 stage proportion ranged from $45.3 \%$ to $47.5 \%$ in MG63 cells with final concentrations of Gas 6 from 0 to $400 \mathrm{ng} / \mathrm{ml}$. There were no significant changes in the G1 stage with Gas6 treatment. The same results were obtained in the osteosarcoma cell line U2OS, in which the G1 stage proportion was $41.9 \%, 40.0 \%, 40.8 \%$, and $42.5 \%$, with concentrations of Gas6 at 0,100 $\mathrm{ng} / \mathrm{ml}, 200 \mathrm{ng} / \mathrm{ml}$, or $400 \mathrm{ng} / \mathrm{ml}$. These results indicated that Gas6/Axl protects osteosarcoma cells from apoptosis with no effect on the cell cycle.

Bcl-2, Bax and P-Axl proteins are highly expressed in osteosarcoma and are related to patient prognosis

By immunohistochemistry staining, the proteins Bcl-2, Bax and
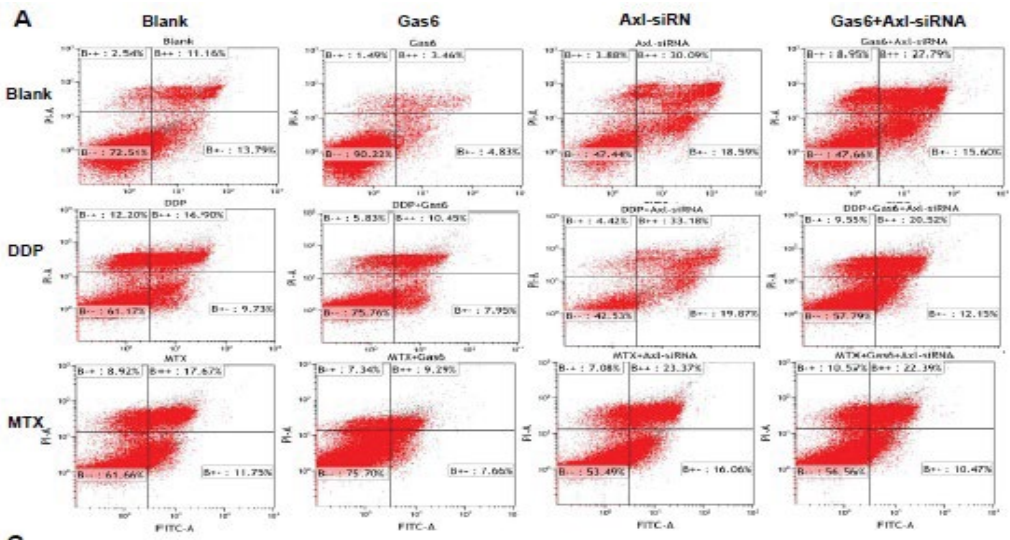

B

Gas6 o ng/ml
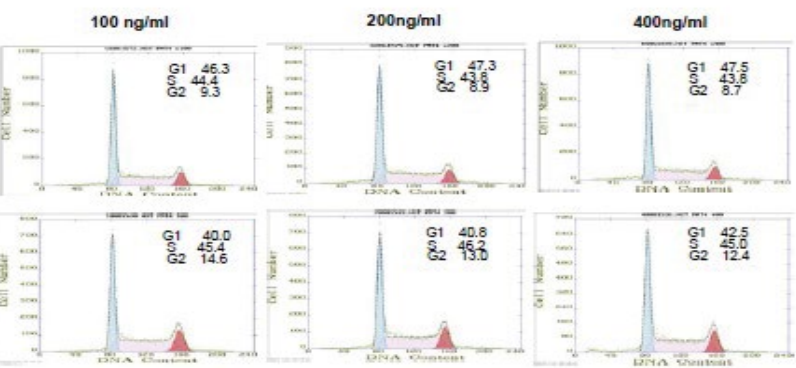

Figure 2: Gas6/Axl inhibited apoptosis of osteosarcoma cells caused by DDP or MTX with no effect on cell cycle. (A) Apoptosis was quantified by Annexin V-FITC staining. MG63 was treated in groups with Gas6 stimulation, AxI-siRNA transfection, or DDP or MTX treatment, similar to the MTT assay. (B) The percent of apoptotic cells decreased in Gas6 stimulated group comparing to that in Axl-siRNA group $(P<0.05)$. And the same results could be seen in DDP or MTX team. (C) The G1 percent was from $45.3 \%$ to $47.5 \%$ when MG63 was stimulated by Gas 6 from 0 to $400 \mathrm{ng} / \mathrm{ml}$. Similarly, the G1 percent was from $41.9 \%$ to $42.5 \%$ when U2OS cells were treated. There were no significant changes in $\mathrm{G} 1 / \mathrm{S}$ of the two cell lines with stimulation of Gas6. 
Citation: Jiang N, Lai Y, Tian R, Xie X, Han J, et al. (2016) Gas6/Axl Inhibits Osteosarcoma Apoptosis through Regulation of Apoptosis-Related Protein Bcl-2. J Bioanal Biomed 8: 001-008. doi:10.4172/1948-593X.1000145

P-Axl were more highly expressed in osteosarcoma tissues than in osteofibrous dysplasia (Figure 3A). Among the 41 osteosarcoma cases, Bcl-2 was positively expressed in 29 cases (70.7\%), whereas among 18 cases of osteofibrous dysplasia, Bcl-2 was positively expressed in 4 cases (22.2\%). Bax was positively expressed in 15 osteosarcoma cases (36.6\%) and in 2 osteofibrous dysplasia cases (11.1\%). Consistently, P-Axl was positively expressed in 35 of 41 osteosarcoma cases $(85.4 \%)$ and was weakly positively expressed in 2 osteofibrous dysplasia cases (11.1\%). Taken together, Bcl-2, Bax and P-Axl proteins in osteosarcoma tissues were significantly higher than in osteofibrous dysplasia $(\mathrm{P}<0.05)$ (Figure 3B).

According to Table 1, there was no significant difference between Bcl-2 or Bax expression and the clinicopathological features including the patient's gender, age, the location of the tumor, histological type and even lung metastasis $(\mathrm{P}>0.05)$. Interestingly, there were significant relationships between the survival status and Bcl-2 or Bax expression $(\mathrm{P}<0.05)$. By Cox univariate analysis of the same group of patients (Table 2), either Bcl-2 or Bax was a predictor of worse prognosis in osteosarcoma, whereas gender, age, primary location and histologic types were not significant predictors of the prognosis.

\section{Bcl-2 expression positively correlated with P-Axl in osteosarcoma tissues}

According to Pearson correlation analysis, the expression of Bcl-2 was positively correlated to $\mathrm{P}$-Axl with statistical significance $(\mathrm{r}=0.842$, $\mathrm{P}<0.0001$ ) (Figure 3C). On the other hand, according to Spearman rank correlation analysis, although the expression of Bcl-2 and Bax have a negative correlative trend in those 41 osteosarcoma cases, there was no significant relationship between them $(r=-0.290, P=0.065)$ (Figure 3C). Conversely, the relationship between Bax and $\mathrm{P}-\mathrm{Axl}$ had no significant correlation $(\mathrm{r}=0.028, \mathrm{P}=0.862)$ (Figure $3 \mathrm{C}$ ).

\section{Overexpression of P-Axl decreased the apoptotic rates in osteosarcoma tissues}

To detect the effect of P-Axl on anti-apoptosis in osteosarcoma tissues, TUNEL assays were carried out. Ten pairs of osteosarcoma cases were selected with higher (Figure 4A) or lower P-Axl expression separately (Figure 4B). In P-Axl higher expression group, the apoptotic rate was almost $1 \%$, whereas it was nearly $7 \%$ in P-Axl lower expression group (Figure 4C). This result supported the opinion that P-Axl could decrease the apoptotic rates even in osteosarcoma tissues.

\section{Discussion}

A previous study demonstrated that activated Axl and its ligand Gas6 promote the progression of osteosarcoma and correlates with worse prognosis of the patients. Moreover, P-Axl could protect tumor cells from cell death induced by serum starvation [20]; whether there is a relationship between Gas6/Axl and apoptosis-related proteins was worthy of investigation. Here, the previous study in osteosarcoma cell lines revealed that Gas6 protected tumor cells from apoptosis, which led to investigations using cytotoxic assays to confirm that Gas6 needs to combine with its specific receptor Axl. Consistently, the apoptosis rates in TUNEL assays were opposite to the expression level
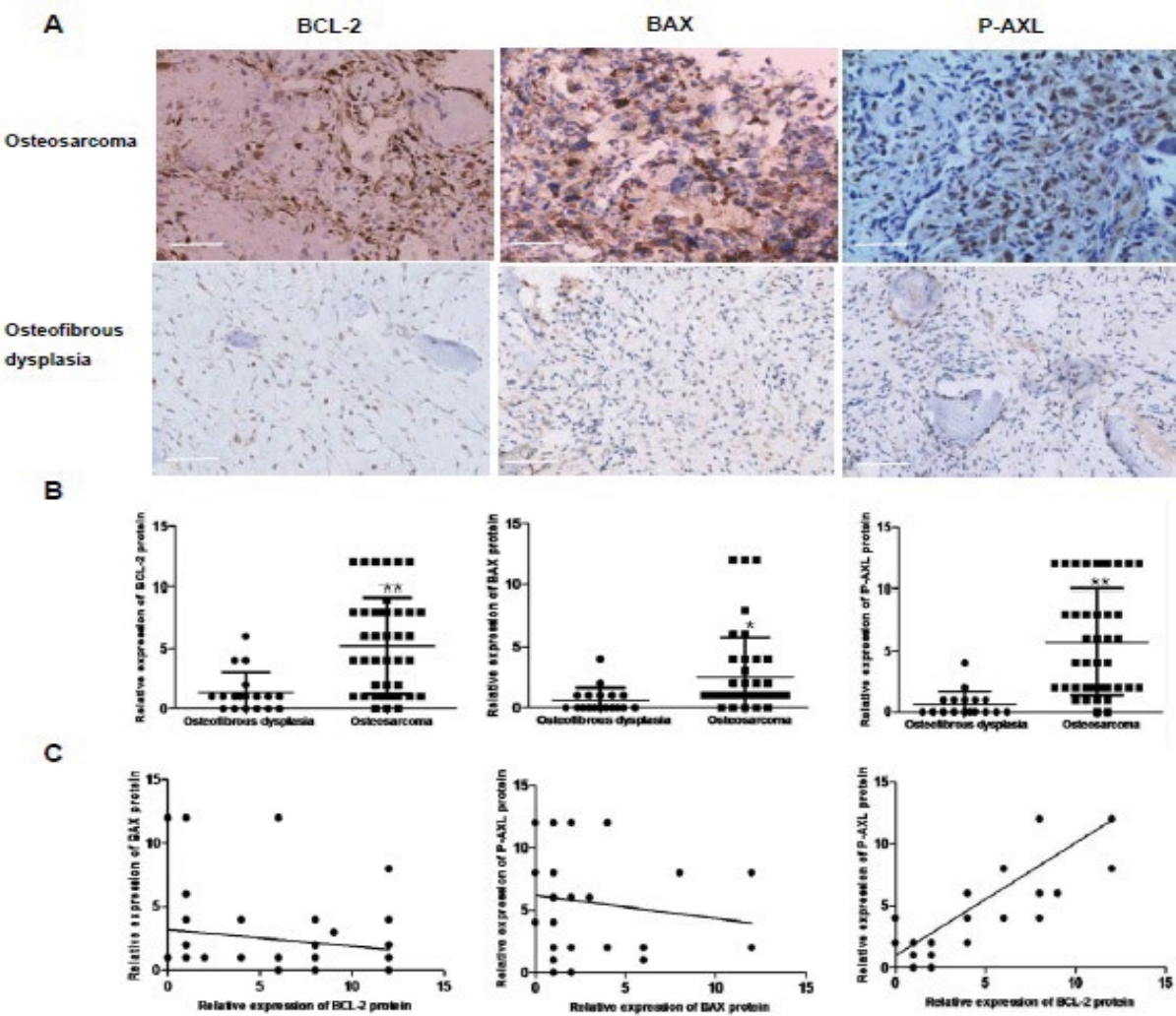

Figure 3: Bcl-2, Bax and P-Axl proteins are highly expressed in osteosarcoma and are related to patient prognosis (A) Protein of Bcl-2, Bax and P-Axl were higher

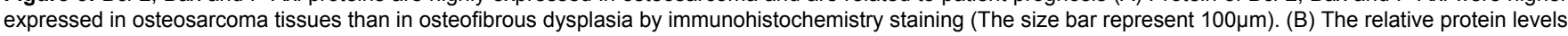
of $\mathrm{Bcl}-2, \mathrm{Bax}$ and $\mathrm{P}-\mathrm{Axl}$ in osteosarcoma were significantly higher than in osteofibrous dysplasia $(\mathrm{P}<0.05)$. (C) According to Pearson correlation analysis, Bcl-2 and $\mathrm{P}$-Axl expression was positively correlated with statistical significance $(\mathrm{r}=0.842, \mathrm{P}<0.0001)$. 
Citation: Jiang N, Lai Y, Tian R, Xie X, Han J, et al. (2016) Gas6/Axl Inhibits Osteosarcoma Apoptosis through Regulation of Apoptosis-Related Protein Bcl-2. J Bioanal Biomed 8: 001-008. doi:10.4172/1948-593X.1000145

\begin{tabular}{|c|c|c|c|c|c|c|c|c|c|}
\hline \multirow{2}{*}{$\begin{array}{l}\text { Clinicpathological } \\
\text { Charecterstics }\end{array}$} & \multirow[b]{2}{*}{$\begin{array}{l}\text { Cases } \\
(n=41)\end{array}$} & \multicolumn{4}{|c|}{ BCL-2 Expression } & \multicolumn{4}{|c|}{ BAX Expression } \\
\hline & & Positive $(n=29)$ & $\begin{array}{c}\text { Negative } \\
(n=12)\end{array}$ & $x^{2}$ & $P$ & Positive $(n=15)$ & $\begin{array}{c}\text { Negative } \\
(n=26)\end{array}$ & $X^{2}$ & $P$ \\
\hline Gender & & & & 1.435 & 0.231 & & & 0.146 & 0.702 \\
\hline Male & 23 & 18 & 5 & & & 9 & 14 & & \\
\hline Female & 18 & 11 & 7 & & & 6 & 12 & & \\
\hline Age & & & & & & & & 0.437 & 0.509 \\
\hline$<18$ & 18 & 15 & 3 & 2.462 & 0.117 & 6 & 12 & & \\
\hline$\geq 18$ & 23 & 14 & 9 & & & 10 & 13 & & \\
\hline Lacation & & & & 6.810 & 0.078 & & & 3.245 & 0.355 \\
\hline Femur & 22 & 17 & 5 & & & 9 & 13 & & \\
\hline Tibia & 14 & 9 & 5 & & & 4 & 10 & & \\
\hline Humerus & 3 & 3 & 0 & & & 0 & 3 & & \\
\hline Ilium & 2 & 0 & 2 & & & 0 & 2 & & \\
\hline Histological type & & & & 1.451 & 0.835 & & & 4.244 & 0.374 \\
\hline Osteoblastic & 8 & 6 & 2 & & & 4 & 4 & & \\
\hline Chondroblasic & 7 & 4 & 3 & & & 2 & 5 & & \\
\hline Fibroblastic & 5 & 3 & 2 & & & 3 & 2 & & \\
\hline Ordinary & 4 & 3 & 1 & & & 0 & 4 & & \\
\hline Others & 17 & 14 & 4 & & & 7 & 10 & & \\
\hline Lung metastasis & & & & 0.366 & 0.701 & & & 0.022 & 0.881 \\
\hline Yes & 11 & 7 & 4 & & & 5 & 6 & & \\
\hline No & 30 & 22 & 8 & & & 11 & 19 & & \\
\hline $\begin{array}{c}\text { Survival status } \\
\text { Alive }\end{array}$ & 25 & 20 & 5 & 4.055 & 0.044 & 6 & 19 & 4.374 & 0.049 \\
\hline Dead & 16 & 9 & 7 & & & 9 & 7 & & \\
\hline
\end{tabular}

Table 1: The relationship between the clinicopathological features of osteosarcoma patients and Bcl-2 or Bax.

\begin{tabular}{|c|c|c|}
\hline Clinicpathologic Characteristics & Hazard ratio $(95 \% \mathrm{Cl})$ & $P$ \\
\hline $\begin{array}{l}\text { Gender } \\
\text { (Male vs. Female) }\end{array}$ & $1.043(0.350-3.107)$ & 0.939 \\
\hline $\begin{array}{l}\text { Age } \\
(<18 \text { years vs. } \geq 18 \text { years })\end{array}$ & $1.226(0.320-4.699)$ & 0.766 \\
\hline $\begin{array}{l}\text { Primary Location } \\
\text { (femur, tibia, humerus, llium) }\end{array}$ & $1.075(0.637-1.815)$ & 0.785 \\
\hline $\begin{array}{l}\text { Histological type } \\
\text { (osteoblastic,chondroblastic,fibroblastic, dilated blood vessels,others) }\end{array}$ & $0.939(0.708-1.246)$ & 0.664 \\
\hline BCL-2 Expression (Low vs. High) & $3.110(1.034-9.354)$ & 0.043 \\
\hline BAX Expression (Low vs. High) & $0.255(0.078-0.838)$ & 0.024 \\
\hline
\end{tabular}

Table 2: Cox Univariate analysis of potential prognostic factors including Bcl-2 and Bax in 41 cases of osteosarcoma patients.

of P-Axl in osteosarcoma tissues, indicating that in tumors, Gas6/PAxl also has the function to help tumor cells to counteract apoptosis. Immunohistochemical analysis revealed a correlation between P-Axl and $\mathrm{Bcl}-2$ or Bax proteins. All three proteins were overexpressed in osteosarcoma compared to that in osteofibrous dysplasia. Bcl-2 or Bax had significant relationships with patients' survival status and were predictors of worse prognosis. Interestingly, P-Axl was found to be positively correlated to the expression of $\mathrm{Bcl}-2(\mathrm{r}=0.842, \mathrm{P}<0.0001)$, demonstrating that $\mathrm{P}-\mathrm{Axl}$ inhibited osteosarcoma apoptosis at least through regulation of the apoptosis-related protein $\mathrm{Bcl}-2$. There could be AKT pathway participation in this regulatory mechanism, and this requires further investigation.

As the downstream of AKt pathway, two apoptotic pathways are demonstrated. Extrinsic pathway which is triggered through death receptors and intrinsic one which is caused by mitochondrial alterations. In the extrinsic pathway, cell death depends on amounts of various members of Bcl 2 family [22]. On the other hand, targeting the AKT/GSK3 $\beta /$ cyclin D1/Cdk4 pathway can be an efficient modality to suppress cell cycle to acquire radio resistance of tumor cells $[23,24]$. In this research work, we have found that Gas6 could protect the osteosarcoma cell lines from apoptosis without effect on the cell cycle, which indicated that Gas6 may regulate cells' apoptosis through AKTBcl-2 pathway, without regulation of AKT-cyclinD1 pathway.

With neo-adjuvant chemotherapy used in a wide range of clinical applications, the 5-year survival rate of patients with osteosarcoma has improved. Recently, however, the resistance to chemotherapy has seriously affected the sensitivity and effectiveness of chemotherapy drugs. In this study, it was proven that Gas6/Axl could obviously promote osteosarcoma cell resistance to the apoptosis induced by DDP or MTX. Similarly, Ye et al. [25] found that anti-Axl monoclonal antibody can enhance the effect of chemotherapy in non-small cell lung adenocarcinoma. Liu L [26] found that Axl expression was highly expressed in breast cancer cell line BT474, which was imatinib tolerated, and showed reduced expression in BT474 cells which was not imatinib tolerated. The chemosensitivity of tumor cells increased after the use of siRNA technology to reduce Axl expression. In addition, Axl was found 
Citation: Jiang N, Lai Y, Tian R, Xie X, Han J, et al. (2016) Gas6/Axl Inhibits Osteosarcoma Apoptosis through Regulation of Apoptosis-Related Protein Bcl-2. J Bioanal Biomed 8: 001-008. doi:10.4172/1948-593X.1000145
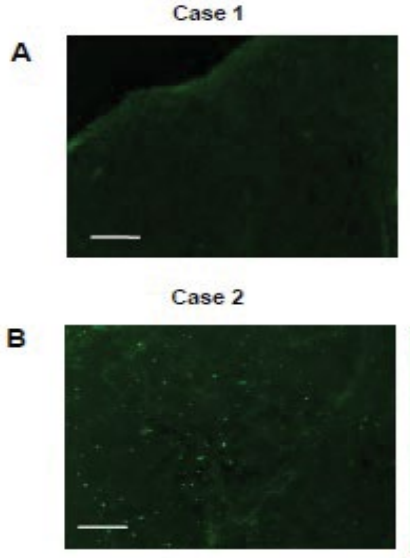

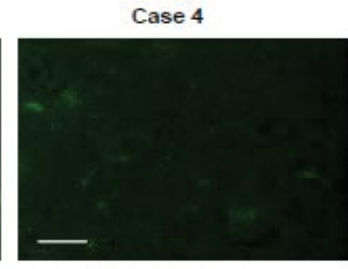

Case 4

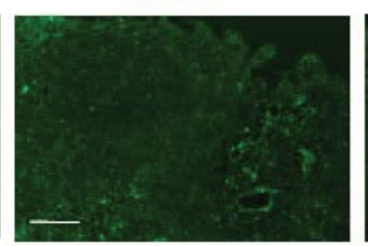

Case 5

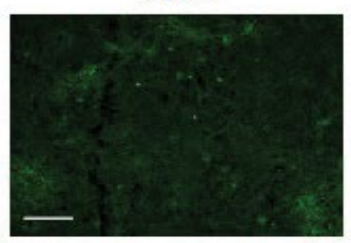

Case 8

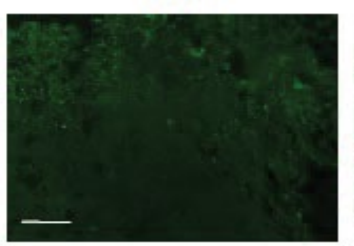

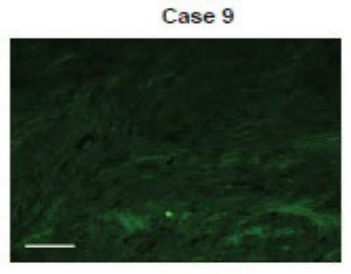

Case 9

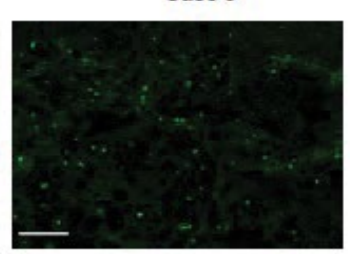

C

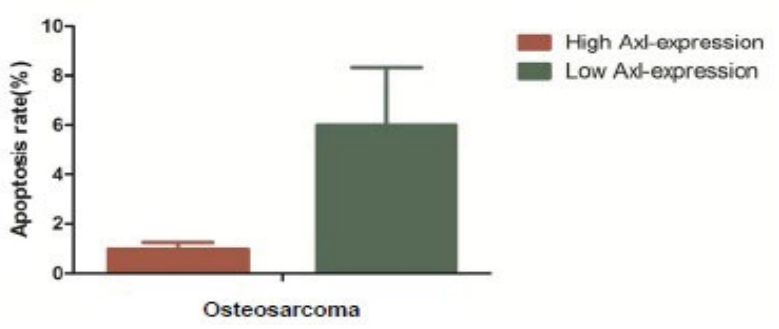

Figure 4: Overexpression of P-Axl decreased the apoptotic rates in osteosarcoma tissues. (A) Osteosarcoma with Axl high expression was assessed by TUNEL assay. (B) Osteosarcoma with Axl low expression was assessed by TUNEL assay. (The size bar represents $500 \mu \mathrm{m}$ ). (C) The apoptotic rate of the P-AxI higher expression group was obviously lower than in $\mathrm{P}-\mathrm{Axl}$ lower expression group $(\mathrm{P}<0.05)$.

to be upregulated in drug-resistant leukemia, and the upregulation might induce drug resistance by increasing the expression of $\mathrm{Bcl}-2$ and twist in the presence of Gas6 stimulation [27]. Conclusively, Gas6/Axl inhibits the osteosarcoma cell apoptosis induced by DDP and MTX and also inhibits apoptosis in osteosarcoma tissue, probably by regulating the apoptosis-related protein Bcl-2. It will be a worthy strategy to target it by inhibiting the expression or activation of Axl for preventing the tumor progression.

\section{Conclusion}

Gas6/Axl partially inhibits the osteosarcoma cell apoptosis induced by DDP and MTX chemotherapy and also inhibits apoptosis in osteosarcoma tissue, probably by regulating the apoptosis-related protein Bcl-2.

\section{Author's Contribution}

Nian Jiang carried out the experiment, drafted the manuscript and performed the literature review; Yingrong Lai carried out the experiment and collected the patients' clinical information; Rui Tian participated in the experiment and performed the statistical analysis; Xianbiao Xie collected the patients' clinical information; Ju Han participated in the cell experiment, Ni Liu and Canqiao Luo participated in the immunohistochemical staining; Tingsheng Peng designed the experiment, reviewed the literature, and revised the manuscript. All authors have read and approved the final manuscript.

\section{Acknowledgement}

This manuscript was supported by the National Natural Science Foundation of China (NSFC) (Grant no.81302348). The manuscript was edited by Nature publishing Group Language Editing.

\section{References}

1. Jaffe N (2009) Osteosarcoma: review of the past, impact on the future. The American experience. Cancer Treat Res 152: 239-262.

2. Liu E, Hjelle B, Bishop JM (1988) Transforming genes in chronic myelogenous leukemia. Proc Natl Acad Sci U S A 85: 1952-1956.

3. O'Bryan JP, Frye RA, Cogswell PC, Neubauer A, Kitch B, et al. (1991) Axl a transforming gene isolated from primary human myeloid leukemia cells, encodes a novel receptor tyrosine kinase. Mol Cell Biol 11: 5016-5031.

4. Ohashi K, Mizuno K, Kuma K, Miyata T, Nakamura T (1994) Cloning of the cDNA for a novel receptor tyrosine kinase, Sky, predominantly expressed in brain. Oncogene 9: 699-705.

5. Schneider C, King RM, Philipson L (1988) Genes specifically expressed at growth arrest of mammalian cells. Cell 54: 787-793.

6. Hafizi S, Dahlback B (2006) Gas6 and protein S. Vitamin K-dependent ligands for the AxI receptor tyrosine kinase subfamily. FEBS J 273: 5231-5244.

7. Hassan M, Watari H, AbuAlmaaty A, Ohba Y, Sakuragi N (2014) Apoptosis and molecular targeting therapy in cancer. Biomed Res Int 2014: 150845.

8. Nicholson DW, Thomberry NA (2003) Apoptosis:Life and death decisions Science 299: 214-215.

9. Moldoveanu T, Follis AV, Kriwacki RW, Green DR (2014) Many Players in BCL2 family affairs. Trends Biochem Sci 39:101-111.

10. Choi JE, Kang SH, Lee SJ, Bae YK (2014) Prognostic significance of Bcl-2 expression in non-basal triple-negative breast cancer patients treated with anthracycline-based chemotherapy. Tumour Biol 35: 12255-12263.

11. Asmarinah A, Paradowska-Dogan A, Kodariah R, Tanuhardja B, Waliszewsk $\mathrm{P}$, Mochtar CA, et al. (2014) Expression of the Bcl-2 family genes and complexes involved in the mitochondrial transport in prostate cancer cells. Int J Oncol 45: 1489-1496.

12. Gryko M, Pryczynicz A, Guzińska-Ustymowicz K, Kamocki Z, Zaręa K, Kemona A, et al. (2012) Immunohistochemical assessment of apoptosis-associated proteins: $\mathrm{p53}, \mathrm{Bcl}-\mathrm{xL}, \mathrm{Bax}$ and Bak in gastric cancer cells in correlation with clinical and pathomorphological factors. Adv Med Sci 57: 77-83. 
Citation: Jiang N, Lai Y, Tian R, Xie X, Han J, et al. (2016) Gas6/Axl Inhibits Osteosarcoma Apoptosis through Regulation of Apoptosis-Related Protein Bcl-2. J Bioanal Biomed 8: 001-008. doi:10.4172/1948-593X.1000145

13. Schlauder SM, Calder KB, Khalil FK, Passmore L, Mathew RA, Morgan MB (2009) Bif-1 and Bax expression in cutaneous Merkel cell carcinoma. J Cutan Pathol 36: 21-25.

14. Pryczynicz A, Gryko M, Niewiarowska K, Cepowicz D, Ustymowicz M, Kemona A, et al. (2014) Bax protein may influence the invasion of colorectal cancer. World J Gastroenterol 20: 1305-1310.

15. Kontos CK, Fendri A, Khabir A, Mokdad-Gargouri R, Scorilas A (2013) Quantitative expression analysis and prognostic significance of the BCL2associated $X$ gene in nasopharyngeal carcinoma: a retrospective cohort study. BMC Cancer 13: 293.

16. Schmidt LH, Görlich D, Spieker T, Rohde C, Schuler M, et al. (2014) Prognostic Impact of $\mathrm{Bcl}-2$ Depends on Tumor Histology and Expression of MALAT-1 IncRNA in Non-Small-Cell Lung Cancer. J Thorac Oncol 9: 1294-1304.

17. Bose P, Klimowicz AC, Kornaga E, Petrillo SK, Matthews TW, et al. (2012) Bax expression measured by AQUAnalysis is an independent prognostic marker in oral squamous cell carcinoma. BMC Cancer 12: 332

18. Trieb K, Sulzbacher I, Kubista B (2013) Bcl-2 correlates with localization but not outcome in human osteosarcoma. Oncol Lett 6: 559-561.

19. Fu T, Xia C, Li Z, Wu H (2015) Lack of association between bcl-2 expression and prognosis of osteosarcoma: a meta-analysis. Int J Clin Exp Med 8: 9093 9099.

20. Han J, Tian R, Yong B, Luo C, Tan P, et al. (2013) Gas6/Axl mediates tumor cell apoptosis, migration and invasion and predicts the clinical outcome of osteosarcoma patients. Biochem Biophys Res Commun 435: 493-500.

21. Zhang Y, Tang YJ, Man Y, Pan F, Li ZH, et al. (2013) Knock ᄀdown of AXL receptor tyrosine kinase in osteosarcoma cells leads to decreased proliferation and increased apoptosis. Int J Immunopathol Pharmacol 26: 179-188.

22. Papadakis ES, Cichoń MA, Vyas JJ, Patel N, Ghali L, et al. (2011) Axl promotes cutaneous squamous cell carcinoma survival through negative regulation of pro-apoptotic Bcl-2 family members. J Invest Dermatol 131: 509-517.

23. Mollazadeh S, Fazly Bazzaz BS, Kerachian MA (2015) Role of apoptosis in pathogenesis and treatment of bone-related diseases. J Orthop Surg Res 10: 15.

24. Shimura T (2011) Acquired radioresistance of cancer and the AKT/GSK3 $\beta /$ cyclin D1 overexpression cycle. J Radiat Res 52: 539-544.

25. Ye X, Li Y, Stawicki S, Couto S, Eastham-Anderson J, et al. (2010) An antiAxl monoclonal antibody attenuates xenograft tumor growth and enhances the effect of multiple anticancer therapies. Oncogene 29: 5254-5264.

26. Liu L, Greger J, Shi H, Liu Y, Greshock J, et al. (2009) Novel mechanism of lapatinib resistance in HER2-positive breast tumor cells: activation of AXL. Cancer Res 69: 6871-6878.

27. Hong CC, Lay JD, Huang JS, Cheng AL, et al. (2008) Receptor tyrosine kinase $A X L$ is induced by chemotherapy drugs and overexpression of $A X L$ confers drug resistance in acute myeloid leukemia. Cancer Lett 268: 314-324. 